NAGY Katalin

\title{
Az oktatás gazdasági értékei
}

Ebben a tanulmányban a hazai oktatás egyéni és társadalmi szintű gazdasági hozamának néhány elemét tekintjük át ${ }^{1}$. A tanulmány célja a hazai oktatás egyéni és néhány társadalmi szintű gazdasági hozamának áttekintése. Az oktatás egyéni hasznára vonatkozó elméletek áttekintése után a tanulmány bemutatja a különböző iskolai végzettségű hazai munkavállalók havi keresetének alakulását, majd az OECD országcsoportok esetében vizsgálja a diplomások bérelőnyének, a diplomások arányának és a gazdasági fejlettségnek a kapcsolatát. Megállapítja, hogy mindegyik országcsoport esetében igaz, hogy a tanulás jó egyéni befektetés és jelentős egyéni hozammal bír, ez még akkor is így van, ha azokban az országokban ahol a kialakult bérkülönbségek nem nagyok ott a diplomás bérelőny kisebb. Ezt követően az oktatás társadalmi hasznaival foglalkozó közgazdasági elméletek áttekintése után az iskolázottság és a gazdasági fejlettség, majd az iskolázottság és munkaerő-piaci sikeresség valamint az iskolázottság és a várható élettartam közötti kapcsolatok vizsgálatára kerül sor. Egyértelműen igazolható, hogy a magasabb iskolázottság magasabb foglalkoztatottsággal és alacsonyabb munkanélküliséggel jár együtt. Ugyanakkor egyes elemzésekben tetten érhető az oktatás minőségének hatása. A tanulmány további kutatási célként ennek a minőségnek, elsősorban a pedagógusok képzésével és továbbképzésével összefüggő a további kutatását fogalmazza meg.

\section{Az emberi tökebefektetés}

A közgazdaságtan kutatói már nagyon korán felismerték, az emberi tőkébe való beruházás jelentőségét. Az emberi tőke elmélet feltételezése szerint az emberek oktatás és képzés révén beruházásokat végeznek a saját termelőképességükbe. E beruházások kapcsán növekszik a termelőképességük, termelékenységük, ezáltal jövőbeli keresetük is magasabb lesz. (Varga, 1998). Az oktatás és a felsőoktatás egyéni értéke, haszna abban áll, hogy az oktatás növeli az egyéni kereseteket. Az egyéni jövedelmek szoros kapcsolatban vannak az iskolai végzettséggel. Azok, akik befejezett középiskolával rendelkeznek, többet keresnek, mint azok, akik nem; akiknek főiskolai, ill. alapképzési diplomájuk van, többet keresnek, mint azok, akik csak érettségiztek; és azok, akiknek mester diplomájuk van, többet keresnek, mint akiknek csak alapdiplomájuk, s a posztgraduális diplomások még ennél is többet. (Hill et al. 2005) Ez alapján megállapítható, hogy nem csak a jelenben elérhető javak és jólét megszerzése érdekében ruháznak be az emberek tőkét, hanem a jövőben realizálható esetleges pénzbeli és nem pénzbeli hozamok elérése miatt is. (Blaug, 2007)

Az úttörők között említhetjük Adam Smith , aki azt mondta, hogy „Az állótőke részének kell tekinteni a társadalom valamennyi tagjának minden gazdaságilag hasznos tudását és képességét. Az ilyen tudás és készség megszerzése tényleges kiadásokat jelent, mivel megszerzőjét neveltetése, tanulmányai vagy tanonckodása idején is el kell tartani: alapjában

\footnotetext{
${ }^{1}$ A tanulmány megírásában jelentős segítséget nyújtott Polónyi István egyetemi tanár, akinek ezúton mondok köszönetet.
} 
véve úgy kell felfogni őket, mint az illető személyben rögzült és megtestesült tőkét." (Smith 1959, 322. o.] Smith a munkamegosztást elemezve megállapítja, hogy az növeli az egy főre jutó jövedelmet, javítja a munka és tőke hasznosulását, lehetővé teszi a szakosodásból fakadó nyereséget, ösztönzi az új termékek és technológiák bevezetését.(Polónyi, 2000)

Smith az egyes foglalkozási területeken dolgozók bérkülönbségeinek okait keresve az oktatási költségek nagyságában jelöli meg annak egyik magyarázatát: “Költséges új gépet azért állítunk üzembe, mert azt várjuk, hogy különleges munkájával, amit teljes elavulásig végez, nemcsak megtéríti nekünk a ráfordított tőkét, hanem ezen felül még meghozza legalábbis a szokásos profitot. Ilyen költséges géphez hasonlíthatjuk az olyan embert, aki sok munkát és időt áldoz, hogy kitanuljon valami különleges készséget és szaktudást igénylő mesterséget. Azt várjuk, hogy a munka, amit magtanult, az egyszerű munka bérén felül megtéríti a tanulásra fordított összes költséget, és ezen felül meghozza egy, a költségösszeggel egyenlő nagyságú tőkének legalábbis a szokásos profitját" (Smith 1992, 110). [...] "Ezen az elven alapul a szakképzett munka és a tanulatlan munka bére közötti különbség" (Smith 1992, 111). Jean Babtiste Say (1821) értelmezése alapján is tőkeként kellene figyelembe venni, az egyének képzettségét és azokat az egyéni képességeket, amelyek megszerzése jelentős költségek vállalása mellett valósulhat meg, ugyanakkor képesek növelni az egyének termelékenységét. (Kiker, 1966, 486)

Marshall $(1947,211)$ fontosnak tekintette az oktatást, hiszen kiemelte, hogy egy jó oktatás jelentős hasznokat eredményezhet még a hétköznapi munkavállaló számára is, mivel az oktatás serkenti a szellemi tevékenységet, valamint intelligensebbé, felkészültebbé, megbízhatóbbá teszi az egyént a munkában, mind az azon kívüli életben. (T. Kiss Judit, 2010)

Goode az Merican Economic Rewiew 1959-ben megjelent írásában a fizikai tőke meghatározása mellett megadta az emberi tőke definícióját is. Véleménye szerint az emberi tőke tartalmazza az egyéni tudását, (szak) képzettségét, hozzáállását, fogékonyságát, és további olyan szerzett egyéni képességet összességét, amelyek révén az egyén hozzájárulhat a termeléshez. A tőke, korábban is figyelembe vett (pl. épületek építésére, talajjavításra, tartós berendezések beszerzésére fordított) kiadások mellett tartalmazza az oktatásra, a képzésre, a az egészségre fordított, valamint a táplálkozás javítását célzó, és a kutatási tevékenységet előremozdító közösségi kiadásokat is. (Goode, 1959,148)

Goode szerint $(1959,149)$ valójában a fizikai és a humán tőke szerepe is meghatározó a gazdasági folyamatokban, a haladásban, a humán tőkének nagyobb prioritást kell adni tekintettel arra, hogy a fizikai tőke használatához a humán tőke egy bizonyos minimum szintje szükséges. Schultz megállapítja, hogy a munkaerő gazdasági szerepében meghatározó jelentőségú emberi tudás hosszú, költséges folyamat eredményeképpen alakul ki, amely leginkább a beruházási folyamathoz hasonlít. Hangsúlyozza, hogy amit fogyasztásnak nevezünk, annak jó része az emberi tőkébe való beruházást jelent (Schultz 1983, 48), és az emberi tőkébe eszközölt ilyen beruházások az egy dolgozóra jutó reáljövedelem növekedésének legnagyobb részét megmagyarázzák. Az összes tőke emberi összetevője igen nagy - írja -, ennek ellenére túlságosan nagy jelentőséget tulajdonítanak a nem emberi 
tőkének, pedig ha az emberi képességek nem tartanak lépést a fizikai tőkével, ez a gazdasági növekedés korlátjává válik.

\section{Az oktatás egyéni hozama}

\section{Keresetek alakulása}

Az oktatás egyéni hozama a bérek és keresetek iskolázottsági szintenkénti alakulásában nyilvánul meg. Magyarországon, az alapbéreket és kereseteket nemzetgazdasági szinten vizsgálva 2004 és 2015 között arra jutunk, hogy az első négy szinten (nyolc általános alatt, nyolc általánossal, szakiskolával, szakmunkásképzővel) nincs kimutatható különbség sem az alapfizetésekben, sem a keresetekben. Ennél magasabb iskolázottság esetében viszont mindegyik kategória az első négytől és lényegében egymástól is szignifikánsan különbözik. Minél magasabb az iskolai végzettség már az érettségitől, annál magasabbak a fizetések. A teljes mintát vizsgálva egyértelmúen megállapítható, hogy az iskolázottsággal arányosan egyértelműen nőnek a bruttó alapfizetések és keresetek is, tehát szignifikánsan több a kereset. $A$ tanulásnak tehát mind az egyén részére (vagyis a nettó jövedelem szerint), mind a társadalom számára (vagyis a jövedelemadó, a fogyasztási adók és a járulékok szerint) pozitív hozadéka van.

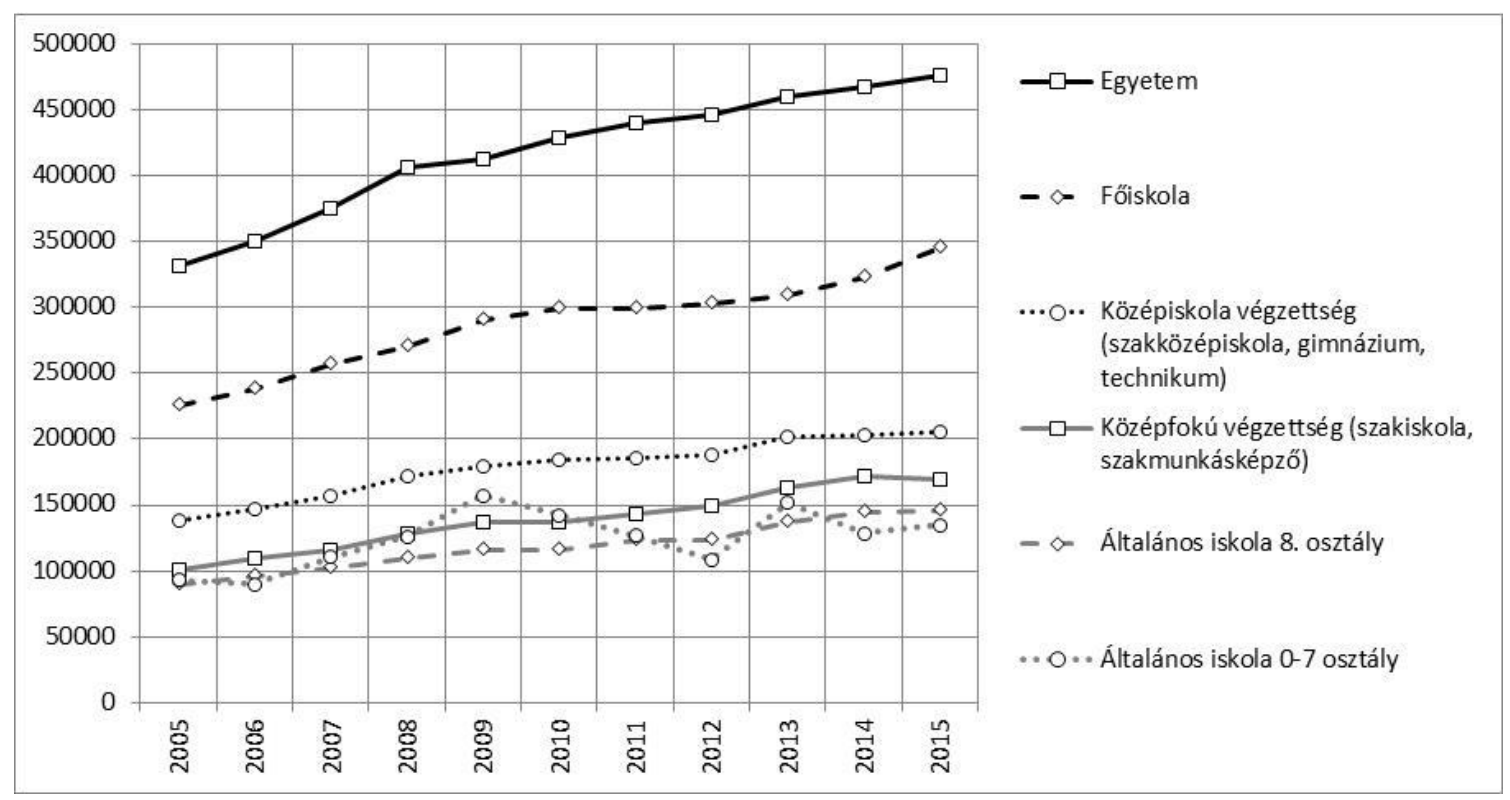

\section{1.Ábra $\mathrm{A}$ havi átlag kerestek (Ft/hó) alakulása befejezett legmagasabb iskolai végzettség szerint, nemenként (2004-2015)}

Forrás: lakossági munkaerő-felmérés 2006-2015, http://nfsz.munka.hu alapján saját szerkesztés 


\section{Gazdasági fejlettség, diplomás arány és diplomás bérelöny}

Az alábbi táblázat az OECD országokban a diplomások arányát, a diplomások bérelőnyét és a gazdasági fejlettséget vizsgálja.

1. Táblázat A gazdasági fejlettség (GDP/fô) a diplomás végzettségúek aránya (a 2564 éves népességen belül) és a diplomásoknak a középfokú végzettségűekhez viszonyított relatív bérelőnyének kapcsolata az OECD országok esetében

\begin{tabular}{|l|c|c|c|c|c|c|}
\hline & \multicolumn{2}{|c|}{$\begin{array}{r}\text { Diplomás arány és a } \\
\text { GDP/fő }\end{array}$} & \multicolumn{2}{c|}{$\begin{array}{r}\text { Diplomás arány és } \\
\text { a diplomás bérelőny }\end{array}$} & \multicolumn{2}{c|}{$\begin{array}{c}\text { GDP/fő és } \\
\text { a diplomás bérelőny }\end{array}$} \\
\hline & Korreláció & $\begin{array}{c}\text { Szignifi- } \\
\text { kancia }\end{array}$ & Korreláció & $\begin{array}{c}\text { Szignifi- } \\
\text { kancia }\end{array}$ & Korreláció & $\begin{array}{c}\text { Szignifi- } \\
\text { kancia }\end{array}$ \\
\hline Magyarország & 0,851 & 0,000 & 0,271 & 0,349 & 0,524 & 0,054 \\
\hline OECD átlag & 0,860 & 0,000 & 0,895 & 0,000 & 0,807 & 0,000 \\
\hline USA & 0,957 & 0,000 & 0,379 & 0,181 & 0,408 & 0,148 \\
\hline Norvégia & 0,933 & 0,000 & $-0,452$ & 0,105 & $-0,580$ & 0,030 \\
\hline Csehország & 0,787 & 0,000 & $-0,608$ & 0,083 & $-0,110$ & $-0,779$ \\
\hline Korea & 0,928 & 0,000 & 0,396 & 0,161 & 0,210 & 0,471 \\
\hline $\begin{array}{l}\text { 2013-as } \\
\text { adatok összes } \\
\text { OECD } \\
\text { országra }\end{array}$ & 0,545 & 0,005 & $-0,341$ & 0,103 & $-0,464$ & 0,023 \\
\hline
\end{tabular}

Forrás: Education at a Glance 2014 OECD alapján saját számítás

A táblázatban látható és vizsgált országokat azért választottam, mert szerettem volna, különböző földrészek gazdaságilag fejlett (USA, Norvégia, Korea) országait összehasonlítani Magyarországgal és az OECD átlaggal. E mellett 2013-as adatok alapján átlagoltam az OECD összes országát.

A diplomások arányát a gazdasági fejlettséggel összehasonlítva elmondható, hogy a vizsgált országok mindegyikében a magasabb GDP, azaz a magas gazdasági fejlettség együtt jár a diplomások arányának magas számával. Tehát minél magasabb az ország GDP-je, annál magasabb a diplomások aránya, illetve fordítva.

A diplomás arányt a diplomások bérelőnyével összevetve az állapítható meg, hogy két típusú országot különböztethető meg. Ahol pozitív a korreláció, ott elmondható, hogy a diplomások magas számához magasabb bér is járul, ahol negatív ott hiába van kevés diplomás, nem kiemelkedően magasabb a bérük. A GDP-t és a diplomások bérelőnyét vizsgálva megállapíthatjuk, 
hogy szinték 2 típusú országot különböztethetünk meg, ahol pozitív a korreláció ott a GDP növekedésével magasabb a diplomások keresete, ahol negatív ott kiegyenlítettebb a társadalmi helyzete az embereknek, mert nem kapnak a magasabb végzetséggel kiemelkedően magas bért. Ha megnézzük, melyek ezek az országok, Norvégia, Csehország és még Koreát is ide venném, ott az emberek fizetése és legmagasabb iskolai végzettsége között nincs olyan nagy különbség, nincs akkora társadalmi szakadék az különböző társadalmi csoportok között. Végeredményben mindegyik országcsoport esetében igaz, hogy a tanulás jó egyéni befektetés és jelentős egyéni hozammal bír, ez még akkor is így van, ha azokban az országokban ahol a kialakult bérkülönbségek nem nagyok ott a diplomás bérelőny kisebb.

\section{Az oktatás társadalmi haszna}

Az elmúlt mindegy évszázadban a közgazdászok jelentős erőfeszítéseket tettek a humántőke gazdasági szerepének vizsgálatát illetően. Az emberi tőke fogalmának fejlesztése és mérése számos területen járult hozzá a gazdasági - társadalmi folyamatok vizsgálatához, mint pl. gazdasági növekedés, oktatás, továbbképzés, migráció, egészségügyi ellátások. (Tóth, 2011) Történelmi előzményként érdemes megemlíteni Fridrich Listet, aki szerint az oktatás olyan növekedési tényező, amelynek növelése érdekében akár nemzedékeken át le kell mondani bizonyos előnyökről, hogy azok később hatványozottan térüljenek meg. „Minden költség, amelyet az ifjúság nevelésére, a jogrend fenntartására, a nemzet védelmére stb. fordítanak, értékek feláldozását jelenti a termelőerők javára. Nagy része annak, amit egy nemzet elhasznál a jövő nemzedékek nevelésére, a nemzet jövőbeni termelőerejének fejlesztését szolgálja" (List,1940,180). List az oktatást, mint a nemzet érdeke szempontjából fontos követelményt tekinti, ami persze hasznot hozhat az egyénnek is (de Listnél a hangsúly a nemzet érdekén van, s kevésbé az egyén hasznán).

Az ember, a képzett munkaerő, mint alapvető termelési tényező, s így mint a gazdasági fejlődés egyik meghatározó tényezője - a fizikai tőke mellett - a neoklasszikus közgazdaságtan egyik alapkérdése. P.H. Douglas amerikai közgazdász és Ch.W. Cobb matematikus a gazdasági növekedést a tőke és a munkaerő figyelembevételével igyekezett megmagyarázni. Majd ezt a technikai haladásnak a figyelembevételével próbálta többek között Robert Solow és Odd Aukrust továbbfejleszteni. Ezt követően egyre több olyan vizsgálat látott napvilágot, amely az egyes országok gazdasági növekedését különböző tényezőkkel igyekszik kapcsolatba hozni. $A$ legismertebb talán Eduard F. Denison (1964) munkája. A szerző többek között az Egyesült Államok gazdaságnövekedési statisztikáinak alapján kísérli meg e növekedés forrásait feltárni és a növekedéshez való hozzájárulásukat számszerűsíteni. Megállapítják, hogy a gazdasági növekedés jelentős eleme az emberi tényező. (Polónyi, 2011)

Adam Smith (1723-1790), a „A nemzetek gazdasága” című munkájában írja, hogy minden gazdaság forrása a termékeny emberi munka, nem pedig a kereskedelem, mint ahogy a merkantilisták állították, s nem is a természet, ahogyan a fiziokraták vélték. Az állótőke részének tekinti "a lakosság, illetve a társadalom valamennyi tagjának minden gazdaságilag hasznos tudását és képességét." (Smith, 2011. I. köt. 300.) J. H. von Thünen (1783-1850) pontosan megfogalmazta az emberi tőke elmélet hipotézisét: „az iskolázottabb népek 
nagyobb tőkét birtokolnak, amelyek hozadéka a munka nagyobb termelékenységében fejeződik ki"(Varga,1998)

A gazdasági növekedés és az oktatás minősége között fennálló kapcsolatot egyre több elemzés bizonyítja. „A közgazdaságtanban az emberi tőke elmélete szolgál a leginkább használható kerettel az oktatás minősége és a gazdasági növekedés közötti összefüggések feltárásához. Bár a gazdaság növekedését az emberi tőke jellemzőivel is magyarázó közgazdasági modelleknek számos variációja létezik, a leggyakrabban használt modellek az endogén növekedési modellek családjába tartoznak. Ezekben a modellekben a tudás, az emberi tőke minősége a gazdasági fejlődés központi magyarázó tényezője.Fazekas (2011) „A témára vonatkozó irodalomból kiemelkednek Eric A. Hanushek és szerzőtársainak elemzései, amelyekben összesítették a nemzetközi kompetenciavizsgálatok eredményeit, és azokat egységes elméleti és módszertani keretbe rendezve nem csupán a növekedés és a kognitív képességek minősége közötti szoros oksági kapcsolat tényét bizonyították, de a modellek adta keretek között számszerűsítették is a sikeres és a nem megfelelően teljesítő oktatási rendszerek gazdasági következményeit. (Fazekas, 2011) (Hanushek -Woessmann (2010a)

„Az oktatás közgazdasági megközelítésének egy másik vonulata az externális hatások vizsgálata. Externáliáról akkor beszélnek a közgazdászok, ha a piacon kapcsolatban álló feleken kívüli külső szereplő, nem szándékoltan, ellentételezés nélkül is élvezi vagy szenvedi egy tevékenység túlcsorduló hatását. Lényegében olyan piaci elégtelenségről van szó, amikor a piacon éppen az ügyletben nem részt vevő jóléti függvénye módosul. Közérthetően az oktatás aspektusából úgy is fogalmazhatunk, hogy azokat a hatásokat nevezzük az oktatás externáliáinak, amelyeket azok élveznek, akik nem vesznek részt az oktatásban. Ezekkel a külső hatásokkal szokták az állam oktatási szerepvállalását indokolni, amelynek legfontosabb érveként azt szokás felhozni, hogy az oktatás kvázi közjószág, és externális hozamokkal jár."(Polónyi, 2016)

A szakirodalom több externális hatást különböztet meg:

- társadalmi kohézióra ható tényezők (Robert Thomas Malthus, Malthus T. R. 1902, Friedman, 1996);

- spillover effect (tovagyürűződő hatás), amely az innovációs teljesítmény növekedésével a gazdaság növekedésére hat (Hill et al., 2005);

- a leginkább ismert externális hatás az iskolázottságnak a munkanélküliség csökkenésére és foglalkoztatás növekedésére való hatása, ami jelentős szociális és foglalkoztatáspolitikai közösségi kiadáscsökkenéssel jár;

- az iskolázottságnak az egészségi és jólléti állapottal való összefüggése szociális és egészségügyi kiadások csökkenését eredményezi (McMahon, 2000);

- az iskolázottságnak a kriminalitás csökkenésére kifejtett hatása;

- és közösségi kiadásokra ható tényezők. ${ }^{2}$

\footnotetext{
2 A magasabban iskolázottak hajlamosabbak magánszolgáltatások igénybevételére, ami közösségi kiadások megtakarítását vonja maga után.
} 


\section{Iskolázottság és gazdasági fejlettség}

Az iskolázottság és gazdasági fejlettség közötti kapcsolat viszonylag egyértelműen látszik, ha az OECD országok iskolázottságát és gazdasági fejlettségét egy diagramon ábrázoljuk.(2. Ábra) Az ábrázolt 28 fejlett ország esetében a korreláció (+0,4312). (Polónyi 2016)

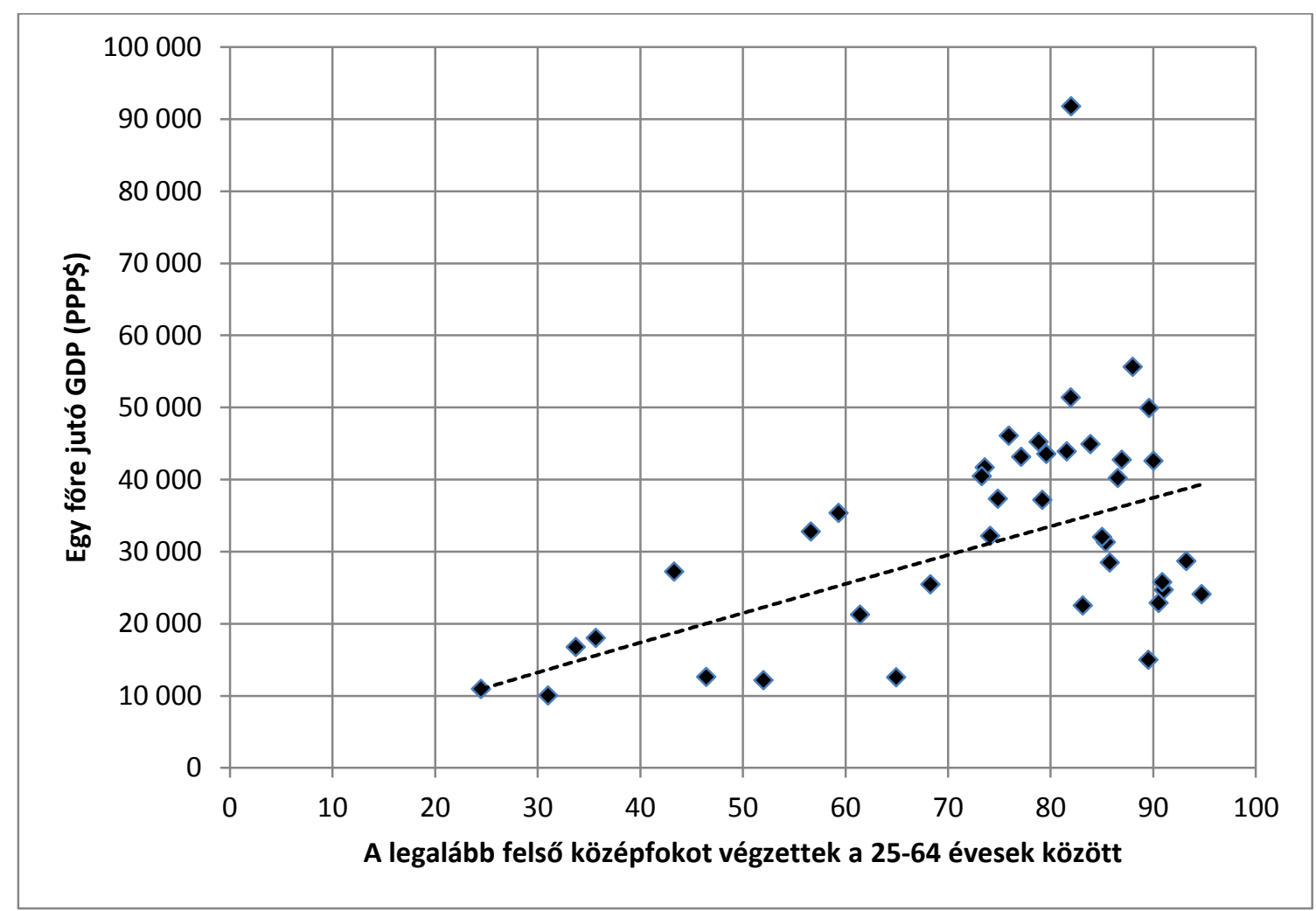

2. Ábra Iskolázottság és a gazdasági fejlettség kapcsolata

Forrás: Education at a Glance 2015 - OECD 2015 alapján saját szerkesztés

\section{Iskolázottság és munkaerö-piaci sikeresség}

A munkaerő-piaci sikerességet két mutatóval mérhetjük legegyszerűbben: a munkanélküliségi rátával és a foglalkoztatási rátával. 


\section{Munkanélküliségi ráta Magyarországon}

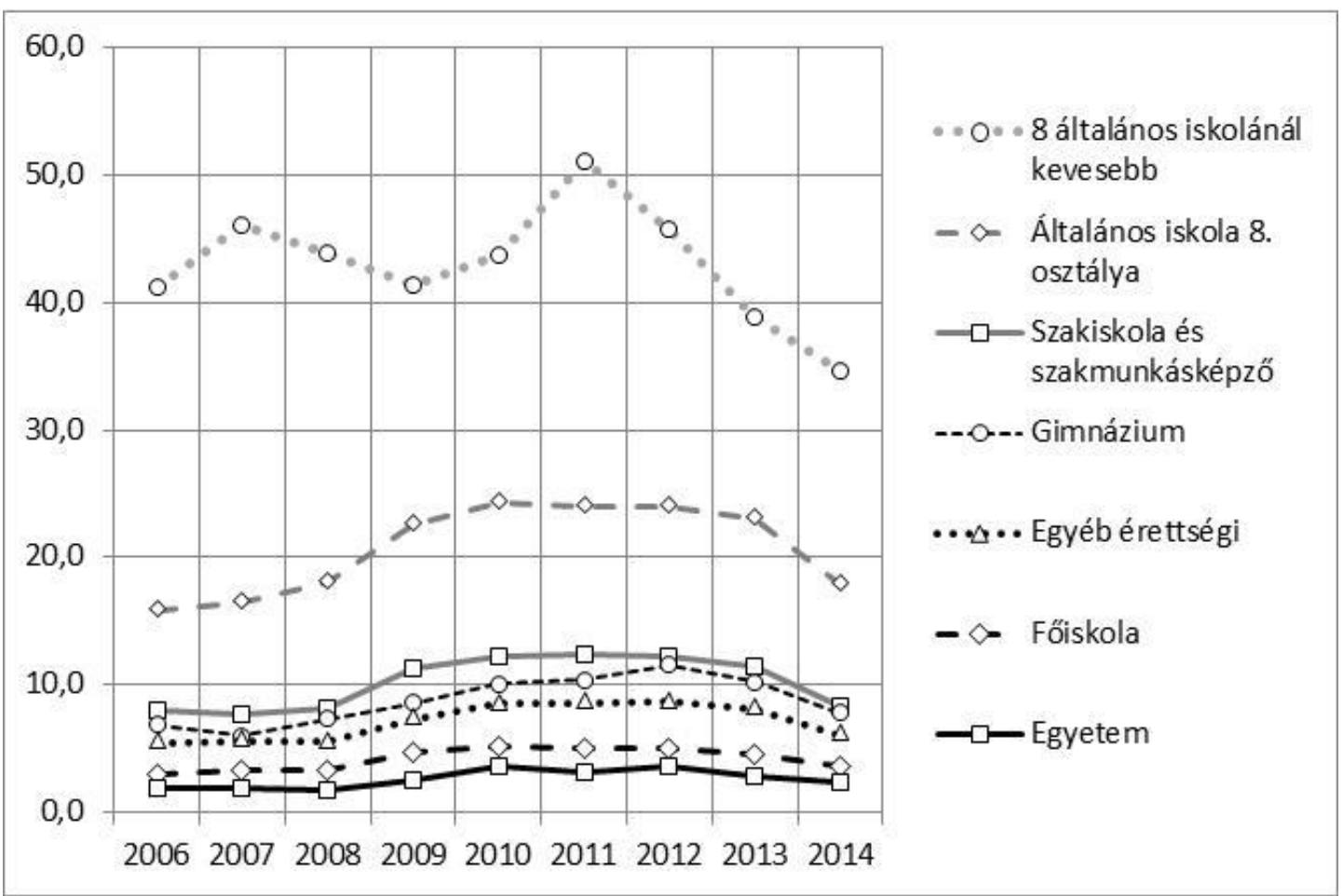

3.Ábra Magyarországon a munkanélküliségi ráta befejezett legmagasabb iskolai végzettség szerint, nemenként (2006-2014)

Forrás: www.ksh.hu alapján saját szerkesztés

A munkanélküliségi rátát vizsgálva megállítható, hogy a 8 általánosnál kevesebbet végzettek között szignifikánsan kiugróan nagyobb a munkanélküliség. Ennél szignifikánsan kisebb, ám a többinél is szignifikánsan nagyobb a ráta a 8 általánost végzettek között. A szakiskola, szakmunkásképző, gimnáziumot végzettek között nincs nagy eltérés, de ez a csoport az alacsonyabb rátájú az előzőeknél és magasabb a következőnél. A főiskolát végzettek szignifikánsan alacsonyabb, az egyetemet végzetteknél pedig még ennél is szignifikánsan alacsonyabb a ráta. 
Hasonló tendenciákat állapíthatunk meg a fejlett országok mindegyikében, azaz a foglalkoztatottsági ráta az iskolázottsággal növekszik, a munkanélküliségi ráta pedig csökken.

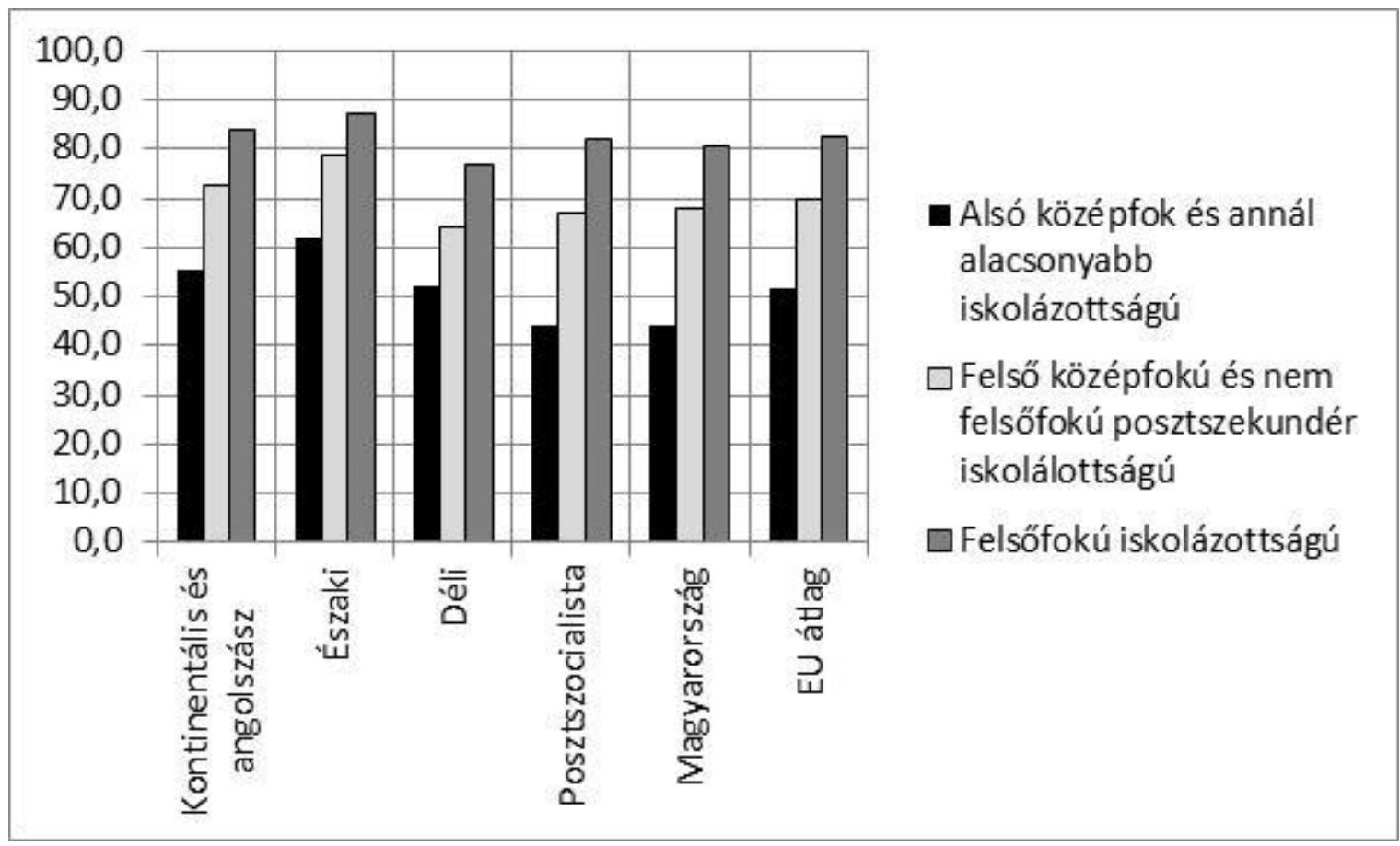

\section{4. Ábra A EU tagország országcsoportonkénti átlagos foglalkoztatási rátája iskolai végzettség szerint a 25-64 éves népesség körében (2013)}

Forrás: http://ec.europa.eu/eurostat alapján saját szerkesztés

Országcsoportok:

- Kontinentális és angolszász: Ausztria,Belgium, Franciaország, Nagy-Britannia, Németország, Svájc, Hollandia, Írország, Luxemburg

- Északi: Dánia, Finnország, Izland, Norvégia, Svédország

- Déli: Ciprus, Görögország, Olaszország, Portugália, Málta, Spanyolország

- Posztszocialista: értelemszerűen a 28 tagországból a korábban államszocialista

Az Európai Unió országainak adatait tekintve szembetűnik, hogy a posztszocialista országok esetében az alacsony iskolázottságú népesség gazdasági aktivitása elmarad az Unió átlagától, miközben ugyanezen népesség munkanélkülisége viszont jelentősen magasabb, mint az EU 
átlaga. Ennek a jelenségnek a mélyebb elemzése túlnyúlik ennek a tanulmánynak a keretein, de alighanem összefügg az oktatás minőségével.

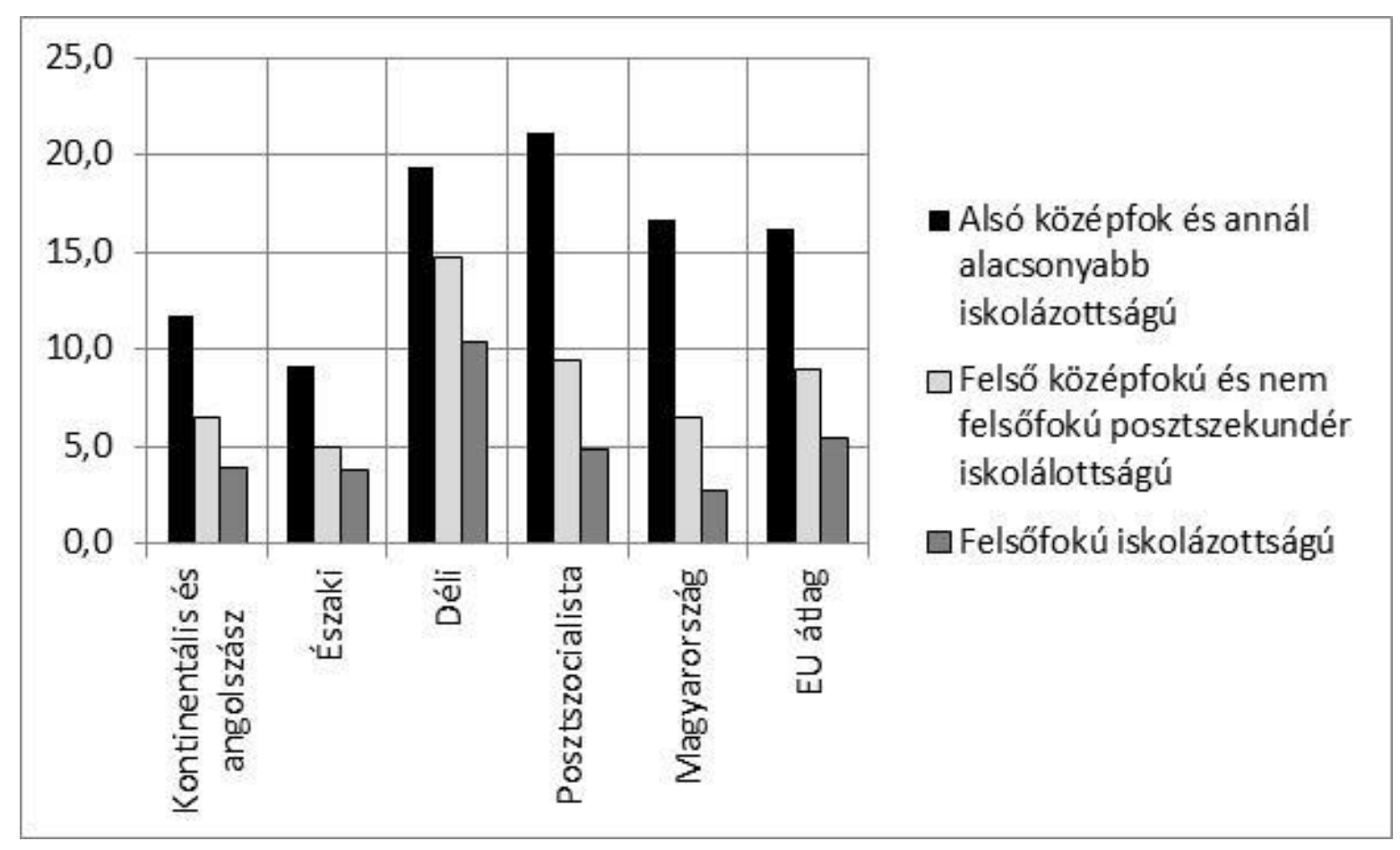

5. Ábra A EU tagország országcsoportonkénti átlagos munkanélküliségi rátája iskolai végzettség szerint a 25-64 éves népesség körében (2013)

Forrás: http://ec.europa.eu/eurostat alapján saját szerkesztés

Az iskolázottság és a munkaerő-piaci sikeresség közötti pozitív kapcsolat tehát kétségtelen. A magasabb iskolázottság magasabb foglalkoztatottsággal és alacsonyabb munkanélküliséggel jár együtt. Az országcsoportonkénti különbségek ugyanakkor az oktatás minőségének jelentőségére hívják fel a figyelmet.

\section{Iskolázottság és várható élettartam}

Robert J. Barro megközelítése szerint az egészségi állapot növeli a termelékenységet, más oldalról az egészségi állapot javulása csökkenti a halálozási rátát és a megbetegedéseket, és így az emberi tőke értékcsökkenését. (Barro, 2013). A gazdagabb országok népessége, sokkal többet tud fordítani egészsége megőrzésére. Ezzel összefüggésben az iskolázottabb népek nagy valószínűséggel tudatosabban élnek, így kevesebbet kell fordítani egészségügyi kiadásaikra. 


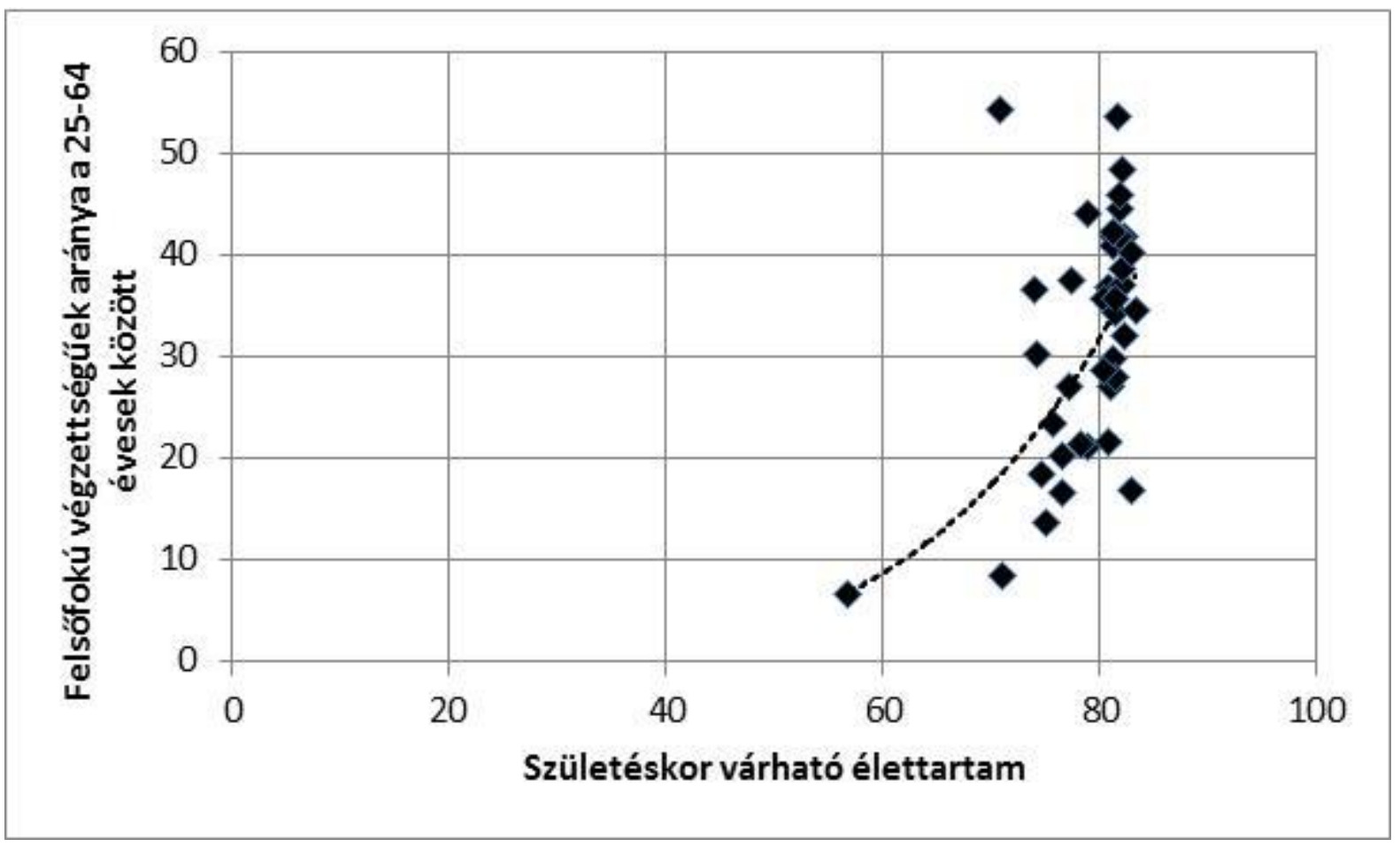

6.Ábra Európában a munkanélküliségi ráta, a legmagasabb iskolai végzettség szerint - MEF adatok (2014)

Forrás: http://stats.oecd.org/Index.aspx?DataSetCode=HEALTH STAT

Mindenesetre ha az európai országokban a 25-64 éves népességen belüli felsőfokú iskolázottságúak arányát és a teljes népesség születéskor várható élettartamát összevetjük, akkor egy viszonylag erős együttjárást tapasztalunk (korreláció +0,4984). Ez arra utal, hogy az iskolázottság növekedésével valóban javul az egészségi állapot.

\section{Befejezés}

Tanulmányunkban áttekintettük az oktatás egyéni és néhány társadalmi hasznát magyarországi és nemzetközi adatok elemzésével. Ezek az elemzések rámutatnak arra, hogy mind az állam, mind az egyén részéről érdemes az oktatásba invesztálni, érdemes időt, pénzt és energiát fordítani. Mint a bemutatott számítások mutatták a tanulás jó egyéni befektetés és jelentős egyéni hozammal bír, ami még akkor is igaz, ha azokban az országokban ahol a kialakult bérkülönbségek nem nagyok ott a diplomás bérelőny kisebb. Az iskolázottság és a munkaerő-piaci sikeresség közötti pozitív kapcsolat is kétségtelen. A magasabb iskolázottság magasabb foglalkoztatottsággal és alacsonyabb munkanélküliséggel jár együtt. Ugyanakkor egyes elemzésekben tetten érhető az oktatás minőségének hatása. További kutatásaimban éppen ezért szeretném megvizsgálni azt, hogy a minőségi oktatásnak és a minőségi oktatóknak, pedagógusoknak mekkora szerep van ezeknek a gazdasági és társadalmi hozamoknak az alakulásában. És ettől nem függetlenül, hogy mekkora a tanárképzések és tanártovábbképzések szerepe az oktatás színvonalában. 


\section{Felhasznált irodalom}

- Becker, G.(1975): Human Capital. The University of Chicago Press, 1975. Chicago

- Bourdieu, P. (2010): Gazdasági tőke, kulturális tőke, társadalmi tőke In.: Angelusz, R, Éber, M Á, Gecser, O: Társadalmi rétegződés olvasókönyv http://www.tankonyvtar.hu/hu/tartalom/tamop425/0010 2A 19 Tarsadalmi retegz odes olvasokonyv szerk Gecser Otto/index.html

- Chevalier, A. and P. Dolton (2004): Teachers' relative pay is a perennial issue: when it's low, graduates are less likely to enter the profession http://cep.Ise.ac.uk/pubs/download/CP164.pdf

- Dolton, P., and O D. Marcenaro-Gutierrez. (2010). "If you pay peanuts do you get monkeys? A cross country analysis of teacher pay and pupil performance." Mimeo. London: Royal Holloway College, University of London.

- Fazekas Károly (2011): Közgazdasági kutatások szerepe az oktatási rendszerek fejlődésében Magyar Tudomány 2011/9

- Hanushek, E. A. - L. Woessmann (2010a): The High Cost of Low Educational Performance: The Long-run Economic Impact Of Improving PISA Outcomes. OECD. Paris http://www.oecd.org/pisa/44417824.pdf

- Hanushek, E. A. - L. Woessmann (2010b): The Economics of International Differences in Educational Achievement (April 2010). National Bureau of Economic Research Working Paper http://www.nber.org/papers/w15949.pdf

- Harbison, F. H. - Ch. A. Myers (1964): Education, Manpower and Economic Growth: Strategies of Human Resources Development, - McGrawe Hill, New York - Toronto London 1964

- List, F. (1940)A politikai gazdaságtan nemzeti rendszere. Magyar Közgazdasági Társaság Kiadása Budapest 1940

- Polónyi István (2002): Az oktatás gazdaságtana: Polónyi, István 2002 Osiris kiadó

- Polónyi István (2011): Az oktatás és az oktatáspolitika közgazdasági ideológiái Educatio 1.

- Schultz Th., W. (1983): Beruházások az emberi tőkébe, KJK, Budapest,1983

- Smith, A.(1992): A nemzetek gazdagsága, Közgazdasági és Jogi Könyvkiadó, Budapest, 1992.

- Tóth László (2011): Az emberi tőke elmélet és alkalmazásának néhány területe

- Varga Júlia (1998): Oktatás-gazdaságtan. Közgazdasági Szemle Alapítvány, Budapest. 